Volume : 6

Nomor : 3

Bulan : Agustus

Tahun : 2020

\title{
Meningkatkan Keterampilan Teknik Lari 100 meter melalui Metode Demonstrasi di Kelas V SDN 3 Kabila
}

\author{
Herni Hamsah \\ SDN 3 Kabila \\ Pos-el: hernihamsah54@gmail.com \\ DOI: 10.32884/ideas.v\%vi\%i.290
}

\begin{abstract}
Abstrak
Tujuan penelitian ini adalah untuk meningkatkan keterampilan teknik lari 100 meter siswa di kelas V SDN 3 Kabila melalui metode demonstrasi. Jenis penelitian ini adalah penelitian tindakan kelas. Hasil analisis data menunjukan adanya peningkatan keterampilan siswa kelas V dalam melakukan teknik lari 100 meter melalui metode demonstrasi. Data observasi awal diperoleh bahwa dari 18 siswa kelas V terdapat 55,6\% atau 10 siswa yang memiliki keterampilan kurang baik. Hal ini kemudian meningkat setelah diberikan tindakan pada siklus I yaitu dari 18 siswa, terdapat 8 orang siswa yang memperoleh nilai kurang dari 75 atau sebanyak 44,5\%. Pada siklus II mengalami peningkatan lagi yakni yang memperoleh nilai 75 ke atas berjumlah 16 orang dengan persentasenya $88,9 \%$ dan daya serap siswa mencapai $83,4 \%$.
\end{abstract}

\section{Kata Kunci}

Metode demonstrasi, teknik lari siswa

\section{Abstract}

The purpose of this study was to improve the students' 100 meter running technique skills in grade V SDN 3 Kabila through the demonstration method. This type of research is classroom action research. The results of data analysis showed an increase in the skills of grade $V$ students in performing the 100 meter running technique through the demonstration method. Preliminary observation data obtained that out of 18 students in grade $V$ there were $55.6 \%$ or 10 students who had poor skills. This then increased after being given action in cycle I, namely from 18 students, there were 8 students who scored less than 75 or as much as $44.5 \%$. In the second cycle there was an increase again, namely those who got a score of 75 and above were 16 people with a percentage of $88.9 \%$ and student absorption reaching $83.4 \%$.

\section{Keywords}

Demonstration method, student running technique

\section{Pendahuluan}

Pendidikan adalah upaya manusia untuk memanusiakan manusia. Sehingga perkembangannya selalu dititik beratkan pada pencapaian sumber daya manusia yang berkualitas. Statemen ini pun berlaku bagi mata pelajaran Pendidikan Jasmani dan Kesehatan materi teknik lari 100 meter. Harus ada inovasi baru yang perlu dilakukan

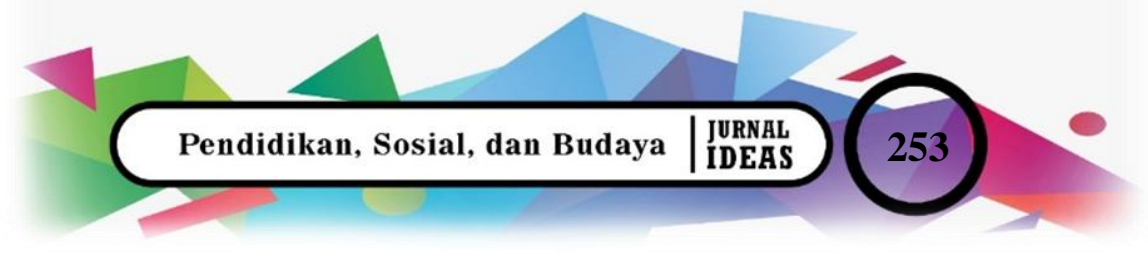


oleh guru dalam meningkatkan keterampilan siswa dalam lari 100 meter. Hal ini perlu dilakukan karena berdasarkan fakta dilapangan, peneliti menemukan bahwa sebahagian besar tenaga pendidik cenderung menggunakan metode pembelajaran yang konvensional. Akibatnya hampir seluruh siswa belum memahami hakikat teknik lari 100 meter, sehingga kompetensi belum sesuai harapan.

Proses pembelajaran pada materi teknik lari 100 meter dengan menggunakan ceramah, memiliki kekurangan yang mengakibatkan siswa hanya mampu menghafal tapi sulit dalam penerapan/praktek. Oleh karena itu, metode demonstrasi diharapkan menjadi solusi terbaik dalam persoalan ini. Hal ini senada dengan pendapat para ahli yang memandang penggunaan metode demonstrasi pada mata pelajaran Pendidikan Jasmani dan Kesehatan sebagai salah satu alternatif yang dapat mengantisipasi berbagai masalah dalam proses kegiatan belajar mengajar, terutama yang berkaitan dengan tingkat penguasaan siswa terhadap materi yang diajarkan bahkan lebih dari pada itu penggunaan metode demonstrasi ini akan mampu menempatkan siswa memiliki pemahaman tentang kejadian yang sebenarnya tentang konsep teknik lari 100 meter. Sehingga hasil akhir yang diharapkan yakni terjadi peningkatan keterampilan siswa dalam teknik lari 100 meter tercapai.

Fakta menunjukan bahwa pada siswa kelas V SDN 3 Kabila yang memiliki siswa sebanyak 18 orang dengan keadaan sekolah yang memiliki sarana dan prasarana optimal, bahwa dalam proses pembelajaran teknik lari 100 meter, dari 18 orang siswa kelas V terdapat $55.6 \%$ atau 10 orang yang memiliki keterampilan kurang baik, sedangkan 8 orang atau $44.5 \%$ telah memiliki keterampilan sebagaimana yang diharapkan.

Dunnette (dalam Iverson, 2001, p. 72) menjelaskan bahwa keterampilan merupakan kapasitas individu dalam menyelesaikan beberapa tugas dari pengembangan hasil training atau pengalaman yang diperoleh.

Metode demonstrasi merupakan penyajian pelajaran yang memperagakan atau mempertunjukan kepada siswa tentang proses,kejadian atau benda yang sedang dipelajari, baik sebenarnya ataupun tiruan dan disertai dengan penjelasan lisan (Djamarah dan Zain, 2010, p. 90). Pendapat ini didukung oleh Roestiyah (2012, p. 82) 


\section{Volume : 6 \\ Nomor : 3 \\ Bulan : Agustus \\ Tahun : 2020}

E-ISSH: 2656-940X 글 P-ISSH: 2442-367K URL: jurnal.ideaspublishing.co.id

yang menyatakan bahwa demonstrasi merupakan proses penerimaan yang berkesan secara mendalam, sehingga dapat menjadikan pengertian dengan baik dan sempurna.

Cara pembelajaran dengan meragakan, mempertunjukkan atau memperlihatkan sesuatu di hadapan murid di kelas atau di luar kelas disebut metode demonstrasi (Aminuddin Rasyad, 2012, p. 1). Dari uraian dan definisi di atas, dapat dipahami bahwa metode demonstrasi adalah dimana seorang guru memperagakan langsung suatu hal yang kemudian diikuti oleh murid sehingga ilmu atau keterampilan yang didemonstrasikan lebih bermakna dalam ingatan masing-masing siswa.

Djamarah dan Zain (2010, p. 91) mengemukakan bahwa metode demonstrasi mempunyai kelebihan dan kekurangan. Berikut ini diuraikan kelebihan dan kekurangannya.

1) Kelebihan Metode Demonstrasi

a. Dapat membuat pengajaran menjadi lebih jelas dan lebih konkret, sehingga menghindari verbalisme.

b. Siswa lebih mudah memahami apa yang dipelajari.

c. Proses pengajaran lebih menarik.

d. Siswa dirangsang untuk aktif mengamati, menyesuaikan antara teori dengan kenyataan dan mencoba melakukannya sendiri.

2) Kekurangan Metode Demonstrasi

a. Fasilitas seperti peralatan, tempat, biaya yang memadai tidak selalu tersedia dengan baik.

b. Demonstrasi memerlukan kesiapan dan perencanaan matang.

Manfaat metode demonstrasi yaitu:

a. Dapat dipergunakan untuk memberikan ilustrasi dalam menjelaskan informasi kepada anak.

b. Metode demontrasi ini dapat dilakukan untuk meningkatkan daya pikir anak, terutama dalam peningkatan kemampuan mengenal, mengingat, berfikir konvergen, dan berfikir evaluatif.

Pada dasarnya penggunaan suatu metode semata-mata membantu kinerja seorang guru bidang studi. Adapun mekanisme serta prosedur pelaksanaannya menurut Djamarah dan Zain (2010, p. 95) adalah sebagai berikut ini. 
a. Tahap Persiapan

1) Menetapkan rancangan tujuan dan tema kegiatan demontrasi

2) Menetapkan rancangan bentuk demontrasi yang dipilih

3) Menetapkan rancangan langkah kegiatan demontrasi

4) Menetapkan rancangan bahan dan alat yang diperlakukan untuk demontrasi

5) Menetapkan rancangan penilaian kegiatan demontrasi

b. Langkah-Langkah Pelaksanaan

1) Kegiatan Prapengembangan

Kegiatan pra-pengembangan merupakan persiapan yang harus dilakukan guru sebelum memulai kegiatan demontrasi, yaitu terdiri dari beberapa tahap berikut ini.

a. Kegiatan penyiapan bahan dan alat yang akan digunakan untuk menunjukkan, mengerjakan, menjelaskan secara terpadu dalam demontrasi sesuai dengan tujuan dan tema yang sudah di tetapkan dan sesuai dengan urutan langkahlangkah demontrasi yang telah ditetapkan.

b. Kegiatan menyiapkan bahan dan alat untuk menirukan pekerjaan seperti yang dicontohkan guru dalam demontrasi.

c. Kegiatan penyiapan siswa dalam mengikuti kegiatan demontrasi dan di ikuti peniruan contoh pekerjaan sesudah demontrasi.

2) Kegiatan Pengembangan

Untuk langkah awal, guru mengajak siswa memperhatikan yang akan dilakukan guru dengan mengajukan pertanyaan kepada siswa yang mengikuti demontrasi. Misalnya, dengan pertanyaan retoris. Pertanyaan retoris mengandung arti pertanyaan itu tidak memerlukan jawaban dari siswa.

c. Kegiatan Penutup

Pada tahap ini digunakan guru untuk memotivasi siswa yang berhasil menunjukkan kinerja yang baik maupun kepada siswa yang kurang berhasil. Siswa yang berhasil menjadi tutor sebaya untuk siswa lainnya.

Hipotesis tindakan dalam penelitian ini yaitu keterampilan siswa di kelas V SDN 3 Kabila pada materi teknik lari 100 meter akan meningkat jika guru menggunakan metode demostrasi dalam pembelajarannya. $75 \%$ dari seluruh siswa yang dikenai 
Volume : 6
Nomor : 3
Bulan : Agustus
Tahun : 2020

E-ISSH: 2656-940X

P-ISSH: 2442-367K

URL:jurnalideaspublishing.co.id

tindakan memperoleh nilai 75 ke atas pada materi sajian merupakan Indikator kinerja dalam penelitian ini.

\section{Metode}

Penelitian ini dilaksanakan di Kelas V SDN 3 Kabila. Waktu penelitian dilakukan dari bulan Januari sampai Februari 2020. Subjek penelitian ini adalah siswa Kelas V SDN 3 Kabila dengan jumlah 18 siswa yang terdiri atas 8 siswa laki-laki dan 10 siswa perempuan.

Prosedur penelitian tindakan kelas terdiri atas 4 langkah yaitu (1) Persiapan, (2) pelaksanaan, (3) Pengamatan, dan (4) analisis dan refleksi. Pengumpulan data dalam penelitian ini menggunakan beberapa teknik yaitu:

a. Observasi

b. Tes

c. Dokumentasi

Dalam menganalisis keterampilan teknik lari 100 meter siswa digunakan berupa tes keterampilan siswa (tes praktek) dengan menggunakan batas skor berdasarkan prosentase. Dengan menggunakan penafsiran acuan patokan (PAP) menurut Salirawati (2011, p. 7) dapat dilihat pada tabel 1.

Tabel 1

Penafsiran acuan patokan (PAP)

\begin{tabular}{ll}
\hline Tingkat Penguasaan & Predikat \\
\hline $85-100 \%$ & Sangat baik \\
$75-84 \%$ & Baik \\
$60-69 \%$ & Cukup \\
$50-59 \%$ & Kurang \\
$\leq 50 \%$ & Kurang sekali \\
\hline
\end{tabular}

Adapun rumus yang digunakan dalam menetapkan daya serap perorangan menurut Salirawati (2011, p. 8) adalah sebagai berikut.

$$
\text { Prosentase nilai } 75 \text { ke atas }=\frac{\text { Jumlah siswa yang tuntas }}{\text { Total jumlah siswa }} \times 100 \%
$$

$$
\text { Daya Serap }=\frac{\text { Total Frekuensi Nilai }}{\text { Total jumlah siswa }}
$$


E-ISSH: 2656-940X
URL:jurnal.ideaspublishing.co.id

Bulan : Agustus

Tahun : 2020

\section{Hasil dan Pembahasan}

Hasil

Penelitian tindakan kelas ini dilakukan di Kelas V SDN 3 Kabila. Peneliti adalah guru PJOK dan sebagai pengamat adalah satu orang guru mitra yang seprofesi untuk mengikuti dan memberikan penilaian terhadap peneliti dalam kegiatan pengambilan data tindakan kelas. Penelitian ini dilaksanakan dalam dua siklus dan diawali dengan observasi awal.

\section{Hasil Observasi awal}

Pada tahap ini, peneliti mengambil data awal tentang kegiatan belajar mengajar pada pembelajaran Penjasorkes materi teknik lari 100 meter masih menggunakan metode lama yaitu ceramah dan penugasan. Dari kegiatan yang dilakukan, diperoleh data yaitu dari 18 orang siswa kelas $\mathrm{V}$ terdapat $55,6 \%$ atau 10 orang yang memiliki keterampilan kurang baik, sedangkan 8 orang atau 44,5\% telah memiliki keterampilan sebagaimana yang diharapkan.

Berdasarkan hasil observasi awal tersebut ditemukan bahwa sebagian besar siswa masih memiliki keterampilan melakukan teknik lari 100 meter yang rendah. Sehingga hal ini membutuhkan tindakan representatif dalam mencari solusi untuk memecahkan masalah keterampilan siswa ini melalui pelaksanaan tindakan siklus I.

\section{Hasil Tindakan siklus I}

Pada proses tindakan siklus I ini dilakukan kegiatan pembelajaran dengan menekankan pada penggunaan metode demonstrasi dalam meningkatkan keterampilan siswa dalam melakukan teknik lari 100 meter. Tindakan pada siklus ini dapat dilihat pada tabel berikut. 
Volume : 6

Nomor : 3

Bulan : Agustus

Tahun : 2020

Tabel 2

Data Hasil Tindakan Siklus I

\begin{tabular}{cccc}
\hline No. & Jumlah Siswa & Nilai & Frekuensi \\
\hline 1 & 1 Orang & 50 & 50 \\
2 & 2 Orang & 60 & 120 \\
3 & 5 Orang & 70 & 350 \\
4 & 6 Orang & 80 & 480 \\
5 & 4 Orang & 90 & 360 \\
\hline \multicolumn{2}{c}{50} \\
\hline \multicolumn{2}{c}{ 18 orang } & \multicolumn{2}{c}{$55,6 \%$} \\
\hline \multicolumn{2}{c}{ Nilai 75 ke atas } & \multicolumn{2}{c}{$75,6 \%$} \\
\hline
\end{tabular}

Sumber data: SDN 3 Kabila, 2020

Berdasarkan tabel hasil tindakan pada siklus I dalam meningkatkan keterampilan siswa melakukan teknik lari 100 meter, dapat dijelaskan sebagai berikut.

a) Dari 18 orang keseluruhan jumlah siswa, terdapat 8 orang siswa yang yang memperoleh nilai kurang dari 75 atau sebanyak $44,5 \%$

b) Dari 18 orang keseluruhan jumlah siswa, terdapat 10 siswa yang yang memperoleh nilai $75 \mathrm{ke}$ atas atau sebanyak 55,6\%

c) Daya serap siswa mencapai $75,6 \%$

Untuk kegiatan guru sebagai mitra pada pelaksanaan tindakan, dalam hal ini peningkatan keterampilan siswa melakukan teknik lari 100 meter dengan menggunakan metode demonstrasi dapat dilihat pada tabel berikut.

Tabel 3

Hasil Pengamatan Kegiatan Guru Pada Siklus I

\begin{tabular}{|c|c|c|}
\hline \multicolumn{2}{|c|}{ Kegiatan Guru } & \multirow{2}{*}{$\begin{array}{c}\text { Prosentase } \\
(\%)\end{array}$} \\
\hline Kualifikasi & Jumlah & \\
\hline Sangat Baik & 0 & 0.00 \\
\hline Baik & 4 & 18,19 \\
\hline Cukup & 10 & 45,45 \\
\hline Kurang & 8 & 36,36 \\
\hline Jumlah & 22 & 100 \\
\hline
\end{tabular}

Sumber data: SDN 3 Kabila, 2020

Berdasarkan tabel kegiatan guru tersebut diperoleh data sebagai berikut.

a) Dari 22 aspek yang dinilai dalam proses pembelajaran, terdapat 4 aspek atau $18,19 \%$ yang memperoleh kriteria baik 
b) Dari 22 aspek yang dinilai dalam proses pembelajaran, terdapat 10 aspek atau $45,45 \%$ yang memperoleh nilai cukup.

c) Dari 22 aspek yang dinilai dalam proses pembelajaran, terdapat 12 aspek atau $36,36 \%$ yang memperoleh nilai kurang.

Di samping itu, data berupa aktivitas siswa dapat dilihat pada tabel berikut ini.

Tabel 4

Lembar Aktivitas Siswa Siklus I

\begin{tabular}{|c|c|c|}
\hline \multicolumn{2}{|c|}{ Aktivitas Siswa } & Prosentase \\
\hline Kualifikasi & Jumlah & $(\%)$ \\
\hline Baik Sekali & 0 & 0 \\
\hline Baik & 1 & 4,35 \\
\hline Cukup & 10 & 43,48 \\
\hline Kurang & 12 & 52,17 \\
\hline Jumlah & 23 & 100 \\
\hline
\end{tabular}

Sumber data: SDN 3 Kabila, 2020

Berdasarkan tabel di atas, dapat dijelaskan bahwa aktivitas siswa dalam Pembelajaran Penjasorkes tentang materi lari 100 meter melalui metode demonstrasi, yaitu sebagai berikut.

1) Dari 23 aspek yang diamati, terdapat 1 aspek yang memiliki aktivitas memuaskan atau sekitar $4,35 \%$

2) Dari 23 aspek yang diamati, terdapat 22 aspek atau 95,65\% yang masih dibawah standar.

Dengan demikian, maka perlu diadakan pembenahan pada siklus berikutnya dengan memperhatikan tilikan dalam refleksi.

\section{Refleksi Siklus I}

Refleksi dilaksanakan pada akhir siklus dengan tujuan untuk mengetahui hasil yang telah diperoleh dan untuk mendapatkan gambaran apakah tindakan yang telah dilakukan telah mempengaruhi peningkatan keterampilan siswa melakukan teknik lari. Berdasarkan kelemahan-kelemahan yang terjadi pada siklus I, dan melihat nilai siswa pada setiap aspek masih rendah dalam melakukan teknik lari 100 meter kelas V SDN 3 Kabila, atau belum mencukupi standar indikator kinerja, maka peneliti bekerja sama 
Volume : 6
Nomor : 3
Bulan : Agustus
Tahun : 2020

E-ISSH: 2656-940X 글

P-ISSH: 2442-367X DI

URL: jurnal.ideaspublishing.co.id

dengan guru sebagai mitra mengadakan kegiatan refleksi untuk menilai kegiatan pembelajaran yang dilaksanakan pada siklus I.

Sesuai dengan hasil refleksi, ditemukan beberapa kelemahan pada pelaksanaan kegiatan pembelajaran mengenai materi teknik lari 100 meter dengan menggunakan metode demonstrasi di kelas V SDN 3 Kabila adalah sebagai berikut.

(a) Penjabaran materi belum efektif.

(b) Langkah-langkah kegiatan belajar mengajar belum efektif dan efisien.

(c) Penguasaan materi pembelajaran belum terlalu mantap.

(d) Pembelajaran cenderung guru yang lebih agresif dibanding siswa.

(e) kurangnya motivasi dan controling, sehingga sebagian siswa hanya bertindak sesuka hati.

(f) Belum maksimalnya pelaksanaan demonstrasi.

(g) Penyimpulan materi belum efisien.

(h) alokasi waktu yang tidak sesuai dengan pembelajaran.

Berdasarkan hasil refleksi bersama dengan guru sebagai mitra kerja, bahwa untuk memeperbaiki kelemahan-kelemahan yang terjadi pada pelaksanaan tindakan pada siklus I dalam meningkatkan keterampilan siswa pada materi teknik lari 100 meter, maka akan disempurnakan pada pelaksanaan tindakan siklus berikutnya, yaitu pelaksanaan tindakan siklus II.

\section{Hasil Tindakan Siklus II}

Pelaksanaan tindakan pada siklus II ini guru sebagai pengajar benar-benar telah menerapkan langkah-langkah pembelajaran yang efektif pada materi teknik lari 100 meter berdasarkan rekomendasi dari hasil refleksi bersama guru sebagai stakeholder.

Dari pelaksanaan tindakan pada siklus II tentang peningkatan keterampilan siswa melakukan teknik lari 100 meter melalui metode demonstrasi diperoleh data sebagai berikut. 
Tahun : 2020

Tabel 5

Hasil Tindakan Siklus II

\begin{tabular}{cccc}
\hline No. & Jumlah Siswa & Nilai pada Setiap Aspek & Frekuensi \\
\hline 1. & 1 Orang & 60 & 60 \\
2. & 1 Orang & 70 & 70 \\
3. & 6 Orang & 80 & 480 \\
4. & 10 Orang & 90 & 900 \\
\multicolumn{2}{c}{ 18 Orang } & & 1510 \\
\hline \multicolumn{2}{c}{ Nilai 75 Ke atas } & $88.9 \%$ \\
\hline \multicolumn{3}{c}{ Daya Serap } & $83.4 \%$ \\
\hline
\end{tabular}

Berdasarkan tabel mengenai keterampilan siswa melakukan teknik lari 100 meter

di kelas V SDN 3 Kabila, diperoleh informasi sebagai berikut.

a) Dari 18 orang jumlah siswa, hanya terdapat 2 orang siswa yang memperoleh nilai 75 ke bawah atau $11,1 \%$.

b) Sedangkan yang memperoleh nilai 75 ke atas berjumlah 16 orang dengan persentasenya $88,9 \%$.

c) Daya serap siswa mencapai $83,4 \%$.

Untuk kegiatan guru pada pelaksanaan tindakan dalam hal ini peningkatan keterampilan siswa melakukan teknik lari 100 meter dengan menggunakan metode demonstrasi di kelas V SDN 3 Kabila, dapat dilihat pada tabel berikut ini.

Tabel 6

Pengamatan Kegiatan Guru Pada Siklus II

\begin{tabular}{|c|c|c|}
\hline \multicolumn{2}{|c|}{ Kegiatan Guru } & Prosentase \\
\hline Kualifikasi & Jumlah & $(\%)$ \\
\hline Sangat Baik & 10 & 45,45 \\
\hline Baik & 11 & 50,00 \\
\hline Cukup & 1 & 4,54 \\
\hline Kurang & 0 & 0.00 \\
\hline Jumlah & 22 & 100.00 \\
\hline
\end{tabular}

Sumber Data: SDN 3 Kabila, 2020

Berdasarkan tabel kegiatan guru tersebut, diperoleh data sebagai berikut:

1) Dari 22 aspek yang dinilai dalam proses pembelajaran, terdapat 10 aspek atau $45,45 \%$ yang memperoleh kriteria sangat baik.

2) Dari 22 aspek yang dinilai dalam proses pembelajaran, terdapat 11 aspek atau 50\% yang memperoleh nilai baik. 
Volume : 6

Nomor : 3

Bulan : Agustus

Tahun : 2020

3) Dari 22 aspek yang dinilai dalam proses pembelajaran, terdapat 1 aspek atau 94,54\% yang memperoleh nilai cukup.

Di samping itu, data berupa aktivitas siswa dapat dilihat pada tabel berikut ini.

Tabel 7

Lembar Aktivitas Siswa Siklus II

\begin{tabular}{ccc}
\hline \multicolumn{2}{c}{ Aktivitas Siswa } \\
Kualifikasi & Jumlah & $\begin{array}{c}\text { Prosentase } \\
(\boldsymbol{\%})\end{array}$ \\
\hline Baik Sekali & 10 & 43,48 \\
Baik & 13 & 56,52 \\
Cukup & 0 & 0 \\
Kurang & 0 & 0 \\
\hline Jumlah & $\mathbf{2 3}$ & $\mathbf{1 0 0}$
\end{tabular}

Sumber Data: SDN 3 Kabila, 2020

Berdasarkan tabel di atas, dapat dijelaskan bahwa aktivitas siswa dalam pembelajaran Pejasorkes materi teknik lari 100 meter dengan menggunakan metode demonstrasi, yaitu:

1) Dari 23 aspek yang diamati, terdapat 23 siswa yang memiliki aktivitas memuaskan atau sekitar $100 \%$.

2) Dari 23 aspek yang diamati, terdapat 0 siswa atau $0 \%$ yang masih di bawah standar.

\section{Refleksi Tindakan Siklus II}

Setelah melaksanakan tindakan pada siklus II, dalam hal ini guru memberikan pelaksanaan tindakan siklus II dengan tujuan agar keterampilan siswa melakukan teknik lari 100 meter melalui metode demonstrasi di kelas V SDN 3 Kabila, bisa meningkat. Setelah dilaksanakannya pelaksanaan tindakan siklus II, maka peneliti dan guru mengadakan kegiatan refleksi untuk membahas hal-hal yang terjadi pada pelaksanaan tindakan pada siklus II.

Berdasarkan hasil refleksi, bahwa walaupun dalam proses pembelajaran yang dilakukan oleh guru masih ada aspek yang kurang, yaitu pada saat peneliti memberikan tindakan kepada siswa, waktu yang digunakan dalam pembelajaran melebihi waktu pelajaran yang telah terjadwal, namun pada pelaksanaan siklus II sudah mencapai indikator kinerja yang telah ditetapkan. Sehingganya pelaksanaan tindakan tidak dilanjutkan lagi ke siklus berikutnya.

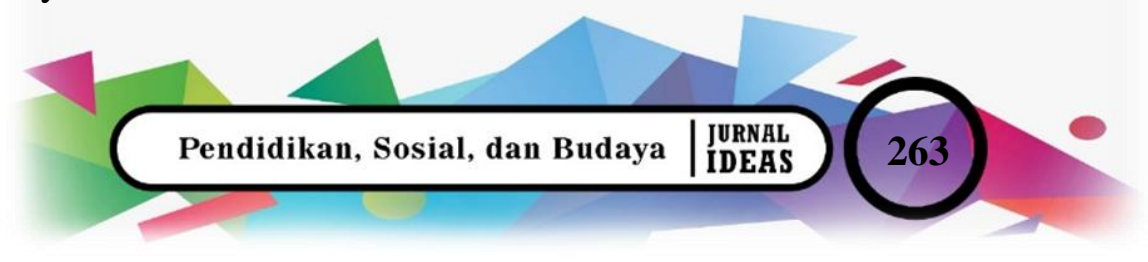




\section{Pembahasan}

Jika dibandingkan dengan indikator kinerja yang telah ditetapkan untuk dicapai pada penelitian ini yaitu $75 \%$ dari siswa yang dapat menguasai materi dengan tingkat penguasan minimal 75 maka dengan hasil yang telah diperoleh menunjukan bahwa sudah tercapai indikator kinerja. Berdasarkan hasil-hasil ini ternyata hipotesis penelitian tindakan yang menyatakan bahwa "jika dalam materi teknik lari 100 meter, guru menggunakan metode demostrasi maka keterampilan siswa di kelas V SDN 3 Kabila pada materi tersebut akan meningkat", teruji kebenarannya.

\section{Simpulan}

Adapun simpulan penelitian ini adalah Metode demonstrasi sangat baik digunakan dalam pembelajaran Penjasorkes materi teknik lari 100 meter di kelas V SDN 3 Kabila khususnya peningkatan keterampilan siswa dalam melakukan berbagai teknik lari 100 meter.

Berdasarkan beberapa simpulan tersebut dapat disarankan hal-hal sebagai berikut. (1) Diharapkan kepada guru Penjasorkes agar dapat menggunakan metode demonstrasi sebagai langkah efektif dalam meningkatkan keterampilan siswa. (2) Diharapkan kepada guru Penjasorkes untuk selalu melaksanakan PTK dalam rangkan memperbaiki dan meningkatkan kualitas proses pembelajaran.

\section{Daftar Rujukan}

Djamarah Bahri Syaiful Drs dan Zain Aswan Drs. 2010. Strategi Belajar Mengajar. Rineka Cipta: Jakarta.

Darsono, Max. 2000. Belajar dan Pembelajaran. Semarang: IKIP Semarang Press.

Dunn, Lee (2000) Theories of Learning. http://www.brookes.ac.uk/services/ocsd/2_learntch/theories.html Iverson.2001. Pengertian Keterampilan dan Jenisnya. http://www.freewebs.com/santyasa/pdf2/pengertian-keterampilan-danjenisnya/\#ixzz1ozJn7QLs akses tanggal 16 Desember 2020.

Peutuah.2012. Metode dan pendekatan pembelajaran. http://www.peutuah.com/metodependekatan-pembelajaran/ akses tanggal 13 Maret 2020. 


\begin{tabular}{l|l} 
Volume : 6 & E-ISSH: 2656-940X \\
Nomor : 3 & P-ISSH: 2442-367K \\
Bulan : Agustus & URL:jurnal.ideaspublishing.co.id \\
Tahun : 2020 & Und
\end{tabular}

Roestiyah, 2012. Strategi Belajar Mengajar. Rineka Cipta: Jakarta.

Suryabrata, Sumadi. 2001. Psikologi Pendidikan. Jakarta: Rajawali Press.

IAAF. 2001. Contoh PTK Penasorkes Untuk SD/Sederajat

http://library.um.ac.id/images/stories/file_bab3_ptknaratif.pdf akses tanggal 16

Desember 2012

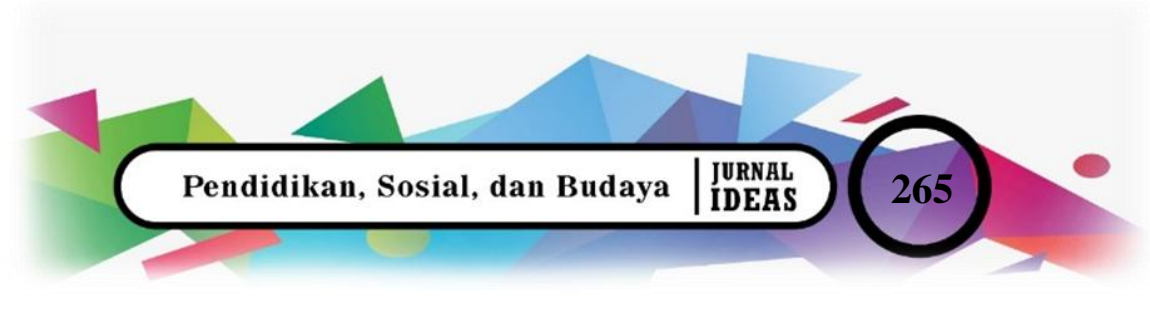




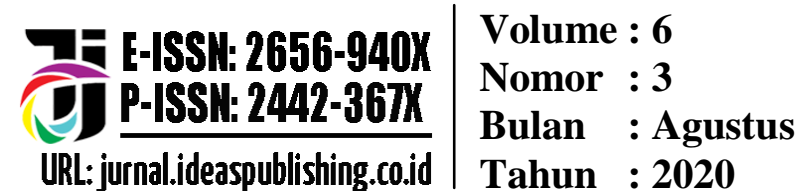

